\title{
4
}

\section{Nordhoff and Hall's Mutiny on the Bounty: A Piece of Colonial Historical Fiction}

\author{
Sylvie Largeaud-Ortega
}

University of French Polynesia

\section{Introduction}

Various Bounty narratives emerged as early as 1790 . Today, prominent among them are one 20th-century novel and three Hollywood movies. The novel, Mutiny on the Bounty (1932), was written by Charles Nordhoff and James Norman Hall, two American writers who had 'crossed the beach $^{1}$ and settled in Tahiti. Mutiny on the Bounty ${ }^{2}$ is the first volume of their Bounty Trilogy (1936) - which also includes Men against the Sea (1934), the narrative of Bligh's open-boat voyage, and Pitcairn's Island (1934), the tale of the mutineers' final Pacific settlement. The novel was first serialised in the Saturday Evening Post before going on to sell 25 million copies $^{3}$ and being translated into 35 languages. It was so successful that it inspired the scripts of three Hollywood hits; Nordhoff and Hall's Mutiny strongly contributed to substantiating the enduring

1 Greg Dening, 'Writing, Rewriting the Beach: An Essay', in Alun Munslow \& Robert A Rosenstone (eds), Experiments in Rethinking History, New York \& London, Routledge, 2004, p 54.

2 Henceforth referred to in this chapter as Mutiny.

3 The number of copies sold during the Depression suggests something about the appeal of the story. My thanks to Nancy St Clair for allowing me to publish this personal observation. 
myth that Bligh was a tyrant and Christian a romantic soul - a myth that the movies either corroborated (1935), qualified (1962; see Jolly \& Petch, Chapter 6) or tried to mitigate (1984). ${ }^{4}$

The axiom adopted here is that a historical novel is a piece of writing whose authors, when reconstructing some past period or event, 'make their best to ensure that their work is historically accurate'. ${ }^{5}$ Through reference to the works of historians, anthropologists, critics in colonial studies and narrative theorists, this chapter explores the gap between what Nordhoff and Hall knew of the Bounty's historical facts ${ }^{6}$ and the facts they chose to deliver in their fiction, in order to raise questions about the novel's literary discourses and genre. Their choice of a fictional white male narrator and protagonist is probed in terms of its impact on their reconstruction of life in Tahiti. Their mise-en-abyme structure, with an older narrator relating the tale of his younger self, raises further questions of narrative reliability and relativism. The overarching purpose of this chapter is to demonstrate that Nordhoff and Hall's discourse is predominantly colonial, ${ }^{7}$ which makes their Mutiny narrative highly partial and contingent historical fiction.

\section{Roger Byam, imaginary protagonist and narrator}

The most blatant invention by Nordhoff and Hall is their replacement of historical Midshipman Peter Heywood with imaginary Midshipman Roger Byam. As the main protagonist and narrator, Byam delivers the Bounty narrative in the form of a memoir written in his old age -

4 For information about the commercial success of Nordhoff and Hall's Mutiny, and a more extensive presentation of the movies, see Greg Dening's Mr Bligh's Bad Language: Passion, Power and the Theatre on the Bounty (Cambridge University Press, 1992, pp 346-79 (henceforth referred to as $B B L)$ ). My thanks to Daniel Margueron for privately supplying further information on the commercial success of Nordhoff and Hall's novel.

5 Sarah Johnson, 'Defining the Genre: What are the Rules for Historical Fiction?', Associated Writing Programs annual conference, New Orleans, Mar 2002.

6 For an exhaustive presentation of Nordhoff and Hall's source material, see their end notes to Mutiny on the Bounty (New York, Boston \& London, Back Bay Books, Little, Brown \& Company, 2003 (1932), pp 382-83).

7 For colonial and postcolonial studies, see the seminal works of Bill Ashcroft, Gareth Griffiths \& Helen Tiffin (eds), The Empire Writes Back: Theory and Practice in Post-Colonial Literature (London, Routledge, 1989); Homi K Bhabha, The Location of Culture (London \& New York, Routledge, 1994); Edward Said, Orientalism (London, Penguin, 1985); Gayatri Chakravorty Spivak, 'Can the Subaltern Speak?', in Patrick William \& Laura Chrisman (eds), Colonial Discourse and Post-Colonial Theory: A Reader (Hennel Hempstead, Harvester Wheatsheaf, 1993). 
in hindsight and as a first-person narrative. Mutiny is the only volume in the Bounty Trilogy that has an imaginary homodiegetic narrator. ${ }^{8}$ What might the authors have hoped to achieve through this choice? One possibility is that it gives the impression of neutrality. Since it is impossible to establish objectively what happened on the Bounty and in Tahiti, the reporting might as well be entrusted to an imaginary character - an outsider who might be presented as neither pro-Bligh nor pro-Christian.

Byam, however, is unmistakably based on historical Heywood. Every single historically known officer and crew from the Bounty is present in Mutiny, except for Heywood, who has been replaced by the nonhistorical Byam. Heywood and Byam share the same profile: each is a young midshipman who claims that he was held on the Bounty against his will at the time of the mutiny, is court-martialled, sentenced to death, finally has his life saved and pursues a brilliant career in the Navy. While Heywood took sides in the Bligh-Christian opposition, he shifted alliances: during the court martial, he protested his utter respect for Bligh - his own life depended on doing so - but, after the court martial, 'the moment he was free of the constraints of appearing innocent', ${ }^{9}$ he was clearly pro-Christian. Given that the Bounty-related experiences of the historical Heywood and non-historical Byam are so similar, why did Nordhoff and Hall elect to use an imaginary protagonist/narrator? What other differences exist between Heywood and Byam that might hint at the grounds for their decision? Why opt for an older narrator reporting on his younger self's experiences? To what extent does this narrative strategy alter facts and shape readers' responses to the text?

From the start of the narrative, Byam is presented as flawless and vulnerable, rather more so than his historical role model. For instance, his birthplace is Somerset, not the Isle of Man where the Heywoods and the Christians were distant relatives, ${ }^{10}$ thus precluding any likelihood of a pre-existing Byam-Christian connivance. Nor can Byam be suspected of belonging to any self-governing island boasting its own

8 A homodiegetic narrator is both narrator and a character in the narrative. For illustrations, see Gérard Genette, Figure III (Paris, Seuil, 1972, pp 225-66). The narrator in Men against the Sea is Thomas Ledward, the historical surgeon acting on board the Bounty launch. In Pitcairn's Island, the narrator is an anonymous omniscient extradiegetic narrator, which means that s/he stands outside the narrative altogether. S/he reports historical Adam Smith's embedded narrative in fictional direct speech in the last chapters.

9 Dening, 1992, pp 257-58.

10 Both families had been established on the Isle of Man for centuries, and had known each other well for generations. 
flag and triskelion emblem (see Utting, Chapter 3): Byam is a true-blue Englishman. He is the only son of a solitary widowed mother and his late father was a maritime scientist held in such high esteem that Sir Joseph Banks himself recommends Byam to Bligh. When Byam embarks on the Bounty, he is a young man who has never been away from home and is innocent of sea life - which is one of the reasons for his dismay at the time of the mutiny.

In reality, Heywood had 10 brothers and sisters, and both of his parents were alive when he departed for Tahiti. Heywood's father was an estate agent with a record blemished by embezzlement. ${ }^{11}$ Heywood was recommended and awarded the privileges of a junior officer, not by Banks, but by Bligh's father-in-law. Finally, like many other young men of that time, Heywood had entered sea service at an early age, ${ }^{12}$ which meant that he possessed significant experience of ship life before he embarked upon the Bounty.

Nordhoff and Hall introduce another major imaginary aspect to Byam: he is a young man with a mission that he alone can accomplish, and is commissioned by none other than Banks. Here is how Bligh introduces the topic in the early pages of Mutiny:

[Sir Joseph Banks] has solicited me most earnestly to employ my time in Tahiti in acquiring a greater knowledge of the Indians and their customs, and a more complete vocabulary and grammar of their language, than it has hitherto been possible to gather. He believes that a dictionary of the language, in particular, might prove of the greatest service with the mariners in the South Sea. ${ }^{13}$

Bligh confesses that he has no gift for languages and so, with Banks' enthusiastic support, the task is bequeathed to the providential Byam. In reality, the historical Bligh had already learnt some Tahitian during Cook's third voyage and, back in Tahiti with the Bounty, 'Bligh was able to converse quite freely with the Tahitians. ${ }^{14}$ What is more, there was no linguistic mission on the historical Bounty: Banks' concern was only for the transfer of breadfruit to the West Indies and the maritime exploration

11 For further information on Peter Heywood's life and career, see WH Smyth, 'A Sketch of the Career of the later Capt. Peter Heywood, RN' (United Service Journal and Naval and Military Magazine, vol 1, 1831a, pp 468-81).

12 At seven, Heywood was captain's servant on the Halifax and, at 14, a trainee on harbour-bound HMS Powerful.

13 Nordhoff \& Hall, 2003, p 10. Further references to this text list page number only.

14 Anne Salmond, Bligh. William Bligh in the South Seas, Auckland, Penguin Viking, 2011, p 169. 
of the Endeavour Straits. ${ }^{15}$ Actual plans for Heywood's Tahitian dictionary did not start until 1792, at the instigation of the budding London Missionary Society. ${ }^{16}$

Nordhoff and Hall's invention of a linguistic mission is fraught with narrative consequences, all of which converge on one point: the aggrandisement of their protagonist/narrator. First, the younger Byam does not just travel to the South Seas; he is asked by Banks to render a 'great service [to] the mariners' of his Majesty's Navy. Second, Byam is a unique and indispensable character with a monopoly on writing; the very valuable proto-ethnographic notes on Tahiti that were taken by historical George Stewart, James Morrison and Bligh ${ }^{17}$ are not mentioned in Mutiny. Third, the young midshipman is propelled to an intellectually (and therefore, albeit unofficially, hierarchically) higher level: he is exceptionally talented where his superior is a self-confessed dunce. Bligh is deficient where Byam is proficient, and thus the Bligh-Byam relationship is under challenge even before the Bounty departs. That challenge concerns the mastery of language - which is quite ironic since, as Greg Dening demonstrates in his decisive Bounty study, historical Bligh's most serious flaw was his 'bad language'. ${ }^{18}$ Fourth, the lurking Bligh-Byam rivalry becomes obvious when Bligh eventually fails in his Bounty mission, while Byam succeeds in his. The breadfruit are lost, but the dictionary lands safely in the lap of Banks who declares: 'It is excellent, Byam; precisely what is needed' (338). Fifth, to

15 The Endeavour Straits were indeed strategically placed in relation to the eastern routes and the colony of New South Wales, and Bligh did chart them during his passage in the Bounty launch.

16 On the history of the London Missionary Society (LMS) Tahitian mission, see John Davis, The History of the Tahitian Mission 1799-1830, CW Newbury (ed) (Hakluyt Society \& Cambridge University Press, 1961); Neil Gunson, Messengers of Grace: Evangelical Missionaries in the South Seas 1797-1860 (Melbourne, Oxford University Press, 1978); KR Howe, Where the Waves Fall: A New South Sea Islands History from First Settlement to Colonial Rule (Honolulu, University of Hawaii Press, 1988); Richard Lovett, The History of the London Missionary Society 1795-1895 (London, Henri Froude, 1899). 17 On Heywood's notetaking, see Rolf Du Rietz, Peter Heywood's Tahitian Vocabulary and the Narrative by James Morrison: Some Notes on their Origin and History (Banksia 3, Uppsala, Sweden, Dahlia Books, 1986). On Morrison's note-taking, see Vanessa Smith \& Nicholas Thomas (eds), Mutiny and Aftermath: James Morrison's Account of the Mutiny on the Bounty and the Island of Tahiti (Honolulu, University of Hawai'i Press, 2013, pp 5-21): 'Only Morrison both lived among the Tahitians and wrote of what he found ... In fact, Morrison might be said to be the first European participant observer of Tahitian society' (p 9). For Bligh, see Salmond (2011): 'Although Joseph Banks has sometimes been called the father of Pacific ethnography, William Bligh's accounts of life in Tahiti are more detailed and astute than anything Banks was able to accomplish - no doubt because of his repeated visits to the island. As his understanding of the language became more fluent and subtle, his reports grew more accurate and insightful. Since Bligh was able to converse quite freely with the Tahitians, he shared more experiences with them; and because Po'e'eno and his father Moana, and Tu and his wife 'Itia, were his bond friends, they were obliged to answer his questions and share their knowledge (even sacred information) with him' (p 169); on Stewart's journal, see this volume's Introduction.

18 See Dening, 1992, pp 57-81. 
modern readers, Bligh's mission appears much less commendable than Byam's 'philosophical' one: the former - helping plantation slave-owners and spurring racial exploitation - epitomises archaism and prejudice; the latter - probing into indigenous Pacific languages - epitomises progress and enlightenment, and heralds ethnographic studies. There is, therefore, little doubt as to whom modern readers will trust. The final point to be made here, giving Byam extra credence in his role as narrator, is that as a master of language (unlike Bligh) he can be relied upon to tell the Bounty story (thereby casting doubt on all other Bounty narratives). Indeed, if on the diegetic level, Banks entrusts the younger Byam with a writing mission, it seems only natural that, on the extradiegetic level, Nordhoff and Hall should entrust the older Byam with a mission to write the Bounty narrative. ${ }^{19}$ When it comes to writing/narrating, Byam stands out as most reliable - or so it seems. He is also, incidentally, endowed with all of the attributes of a worthy young white male hero, as befits the genre of popular historical novels.

\section{Life on board HMAV Bounty}

What does Roger Byam narrate of life on board HMAV Bounty? The backbone of the story is true to history: the ship's course, the major dates and the food rationing are consistent with historical records. Byam's portrayal of William Bligh's character, however, impacts upon the tale of life on board.

Byam does praise Bligh's navigational skills - those could hardly be gainsaid, given Bligh's outstanding achievement in making the Bounty launch's passage to Timor. The way Byam delivers his praise is, however, worth a close reading: 'in justice to an officer whose character in other respects was by no means perfect, I must say that there was no finer seaman and navigator afloat at the time' (29, my italics). The eulogy is heavily counterbalanced, with faults and merits weighing against each other. The tone sounds so constrained that the reader cannot help but feel the antiphrastic value of the rhetorical 'I must say'. Byam's use of the word 'justice' seems equally reluctant. The same semantic pattern of begrudged

19 Diegetic level: narrated level, or the fiction world. Extradiegetic level: writing level, or the real world - with real people, like writers Nordhoff and Hall, and flesh and blood readers. For more detailed definitions of both terms, see Genette (1972, pp 225-66). 
justice and the same counterpoise often recur in the narrative where Bligh is concerned, which evinces how difficult it is for Byam to sound impartial to Bligh.

From the start of the novel, the older Byam presents Bligh as uncouth and violent. The Bounty is still at Spithead when Bligh introduces the younger Byam to sea law by having him attend the flogging around the fleet of a man who has just died under the lashes: 'From neck to waist the cat-o'-nine-tails had laid the bones bare, and the flesh hung in blackened, tattered strips' (23). After witnessing the flogging of the corpse with a smile, without a transition Bligh proceeds to take 'his soup with relish, and sounds better fitted to the forecastle than aft' (25). Indiscriminate flogging and 'masting' subsequently become part of the voyage. In a chapter entitled 'Tyranny', there is a vivid description of the first Bounty flogging:

A great red welt sprang out against the white skin, with drops of blood trickling down on one side. Mills was a burly ruffian and he endured the first dozen without crying out, though by that time his back was a red slough from neck to waist. (52-53)

And yet, Greg Dening counters, 'the cat rarely broke the skin in a dozen lashes'. ${ }^{20}$ The same chapter depicts the 'masting' of young Midshipman Tinkler on an 'icy cold' night, from which he comes down 'blue with cold, unable to stand up or to speak' (56). In history, it was Peter Heywood, not Tinkler, who was thus 'masted'. ${ }^{21}$ In Mutiny, Bligh also has a midshipman (Edward Young) flogged, which 'was almost without precedent' (61). There seems to be no historical record of that particular flogging.

It might therefore come as a surprise that Byam's reports of subsequent punishments should be true to record. Master-at-arms Charles Churchill is given 'two-dozen lashes', and Able Seamen John Millward and William Muspratt 'four-dozen each' (105) for jumping ship in Tahiti. What the narrative fails to say, however, is that desertion was a capital offence (see Utting, Chapter 3) so the punishment was lenient. This is true also for Midshipman Thomas Hayward, who was only disrated for being

20 Dening, 1992, p 64.

21 Heywood reported this 'masting' to WH Smyth only years later, so it may have been altogether spurious. Glynn Christian - a descendant of Fletcher Christian by five generations - signals that Heywood made no mention of it in the long letter he wrote from the Cape of Good Hope, a few weeks after the alleged event. Christian conjectures that Heywood may have made this late addition in order to demonise Bligh. See WH Smyth, 'The Bounty Again!' (United Service Journal and Naval Military Magazine, vol 3, 1831b, p 305); and Glynn Christian, Fragile Paradise: The Discovery of Fletcher Christian Bounty Mutineer (Boston, Little, Brown, 1982, in Dening, 1992, pp 67-69, 312). 
asleep at watch during the desertion. Predictably enough, Mutiny does not indicate that, contrary to the practices of Captain Cook, Bligh neither took Tahitians hostage, nor did he have their ears cut off.

Older narrator Byam may therefore be said to deliberately construct the fantasy of a violent captain Bligh. And it is a fantasy, Bligh was not a physically violent man: 'Bligh's passions were verbal, not physical'22 (see this volume's Introduction). The purpose of this chapter is not to examine Bligh, nor to apportion blame for the mutiny. Neither is it to disentangle what Heywood actually did during the mutiny: he claimed during his trial that he had meant to leave the Bounty in the launch, but a series of circumstances prevented him from doing so - a situation in which the younger Byam also finds himself. ${ }^{23}$ Rather, this chapter aims to reflect upon narrative strategies. So far, the differences between Heywood and Byam all contribute to make the younger Byam appear blameless. Unlike Heywood, Byam has never done anything wrong - he has not even been 'masted', so he cannot be suspected of bearing any personal grudge against Bligh. He is an innocent young man with a clean record. In Byam's narrative of life on board HMAV Bounty, Nordhoff and Hall create a seemingly flat, two-dimensional protagonist who is likely to appeal to a wide readership of popular literature. By allowing narrator Byam to replicate the Heywood party's skewed perspective, the authors also contribute strongly to the myth of Bligh as a violent man.

\section{Life in Tahiti: Vahine and sex}

What about Roger Byam's narrative of life in the Pacific Islands? Mutiny devotes less than two pages to the mutineers' three-month stay in Tubua' $i$ (165-67): 'I shall give [Tubuaians] no more space than they deserve' (165), the narrator spurns. In those three months, however, there was constant fighting because Tubuaians were unwaveringly hostile to the Bounty's would-be settlers (see Teriierooiterai, Chapter 1). The narrative strategy of avoiding commentary on the interaction between mutineers

22 Caroline Alexander, The Bounty: The True Story of the Mutiny on the Bounty, London, Penguin Books, 2003, p 138.

23 See Heywood's Letters in Donald A Maxton \& Rolf E Du Rietz (eds), Innocent on the Bounty: The Court-Martial and Pardon of Midshipman Peter Heywood, in Letters by Peter Heywood and Nessy Heywood (Jefferson, NC, McFarland, 2013). 
and the Islanders actually speaks volumes: Mutiny will not dwell on any representation of Eastern Polynesians that might stain the stereotype of the Noble Savage. ${ }^{24}$

The narrative of life in Tahiti introduces two major differences between Heywood and Byam. The first one bears on sex and romantic love. The resounding successes of Louis-Antoine de Bougainville's Voyage (1771), ${ }^{25}$ John Hawkesworth's Voyage $(1773)^{26}$ and the pamphlets and parodies of Joseph Banks' sexual adventures in Tahiti ${ }^{27}$ had nurtured collective European fantasies that Tahiti was a hotbed of unbridled erotic pleasure. The Bounty company succeeded in living out this fantasy. After their first five-month stay in Tahiti, 40 per cent of them, including Fletcher Christian and Peter Heywood, had caught 'the venereals'. Mutiny, however, tells a different tale. It gives no hint of Christian's reputation from his previous voyage as 'one of the most foolish young men I ever knew in regard to the sex', recorded by Edward Lamb from the Britannia. ${ }^{28}$ Mutiny confirms Edward Christian's contention in the Pamphlet 'Appendix' that Christian had 'no traffic with the women who infested the ship' (92). Instead, Christian forms in time an exclusive 'attachment to Maimiti ... of the tenderest description' (107). Historical Mauatua was indeed Christian's lover and, after the mutiny, she willingly went away with him to both Tubua ${ }^{4}{ }^{29}$ and Pitcairn. Too little is known,

24 In contrast to Eastern Polynesians, Western Polynesians are the stereotypical Ignoble Savages, as demonstrated in Mutiny by the serious troubles experienced on the Friendly Islands and, in Men against the Sea, all islands west of Tahiti. The distinction was first made by early European explorers like Bougainville and Cook. For the stereotype of Tahitians as Noble Savages, see AO Lovejoy \& G Boas, 'Islands of the Blest', in Primitivism and Related Ideas in Antiquity (New York, Octagon Books, 1980, pp 290-367).

25 Louis-Antoine de Bougainville, Voyage autour du Monde par la Frégate du Roi La Boudeuse et la Flûte l'Etoile (1767-68), Paris, La Découverte Poche, 1997 (1771), pp 138-53.

26 Hawkesworth's Voyage dramatically revamped Samuel Wallis, Banks and Cooks' Tahitian notes. For more on Bougainville, Cook and Hawkesworth, see Anne Salmond, Aphrodite's Island. The European Discovery of Tahiti (Berkeley \& Los Angeles, University of California Press, 2009); and Salmond (2011, pp 17-19); Rod Edmond, Representing the South Pacific: Colonial Discourse from Cook to Gauguin (Cambridge, Cambridge University Press, 1997, p 69); Serge Tcherkézoff, Tahiti - 1768. Jeunes Filles en Pleurs. La face cachée des premiers contacts et la naissance du mythe occidental (Pirae, Au Vent des Îles, 2004); Sylvie Largeaud-Ortega, 'Stevenson's The Ebb-Tide, or Virgil's Aeneid Revisited: How Literature May Make or Mar Empires' (Victorian Literature and Culture, vol 41, 2013, pp 567-69); Ainsi Soit-Île. Littérature et anthropologie dans les Contes des Mers du Sud de RL Stevenson (Paris, Honoré Champion, 2012, pp 35-118).

27 For a discussion of contemporary comments on Banks' pranks, see Colin Roderick, 'Sir Joseph Banks, Queen Oberea and the Satirists', in Veit Walter (ed), Captain James Cook: Image and Impact. South Sea Discoveries and the World of Letters (Melbourne, Hawthorne Press, 1972, pp 67-89).

28 Dening, 1992, p 311.

29 The Bounty briefly called at Tahiti before heading for Tubua'i. See Smith \& Thomas (2013, pp iii-xv). 
however, to ensure that she was his one and only partner in Tahiti. In contrast with Heywood, Byam remains a virgin during his first Tahitian stay. This narrative choice confirms that, at the time of the Bounty mutiny, Byam was an inexperienced, innocent young man with very high moral standards. He cannot be suspected of being prompted by either love or lust to return to Tahiti, unlike the mutineers who famously cheered: 'Huzza for Tahiti!' (141). ${ }^{30}$

It is only during the second stay in Tahiti, after the mutiny, that Byam 'cease[s] to be a boy and be[comes] a man' (173). Like Heywood, Byam settles down to a 'life of tranquil happiness' (189) and, unlike Heywood, he fathers a daughter. ${ }^{31}$ His love story, however, starts in a dramatic way. It is requited love at first sight and, on the day the two exchange their first few words, they decide to wed. Once again, the guiding principle seems to be that there should be nothing illegitimate about Byam, at least from a European perspective (Tahitians saw no harm in free unions). Also, Byam is made to become a literary heir to Christian: with Christian now gone forever, Byam becomes the next romantic figure on Tahitian soil. Christian is a sombre Hamlet-like doomed figure: ${ }^{32}$ 'the ardour of his nature, his handsome person and changing moods, made him what women call a romantic man' (93). Byam is a blissful prelapsarian character, beatifically repeating himself: 'It means little to say that I was happy with Tehani' (189), 'That year of 1790 was the happiest and seemed the shortest of my entire life' (203). Both white male archetypes in their own ways allow the popular cliché of South Sea romanticism to endure.

Female characters, on the other hand, seem to be the type of the South Sea vahine redeemed. Nordhoff and Hall's narrator is an ardent vindicator of the virtue of Tahitian women, in reaction against their reputation as 'wanton'. ${ }^{33} \mathrm{He}$ acknowledges that 'as regards the possibilities of dissipation, to which seamen are given in every port, the island could only be described as a Mohammedan paradise' (89). Repeating James

30 In his 21st-century Mutiny on the Bounty historical novel, John Boyne turns the scale against Heywood, by having aptly named Turnstile, the young cockney first-person narrator, call 'scrawny, pimpled Heywood' a 'scut'. He accuses him of being a liar, a Peeping Tom and a deliberate homewrecker (London, Black Swan, 2008, pp 341-43).

31 'No child of Heywood is mentioned' in any source material (Alexander, 2003, p 309).

32 See Edmond (1997, p 75).

33 See John Hawkesworth, An Account of the Voyages Undertaken by Order of Her Present Majesty for Making Discoveries in the Southern Hemisphere and Successively Performed by Commodore Byron, Captain Wallis, Captain Carteret and Captain Cook, in the Dolphin ..., Drawn up from the Journals... (London, W Stratham, 1773). 
Morrison's journal almost word for word, however, he argues that 'to form an impression of the ladies of Tahiti from the women who visited his ships would be like judging the virtue of Englishwomen from a study of the nymphs of Spithead' (83). ${ }^{34}$ Against Bougainville, Hawkesworth and collective South Sea phantasmagoria - and, more importantly still, against American anthropologist Margaret Mead's recently published and bestselling Coming of Age in Samoa (1928) - older Byam declares 'this is, perhaps, a fitting place to say a word for the Indian ladies, so often and so shamelessly slandered by the different navigators who have visited this island' (82). In a brave display of cultural relativism, the authors have their narrator contend that ' $[\mathrm{n}] \mathrm{o}$ women in the world are more modest than the ladies of Tahiti, but they bare their breasts as innocently as an Englishwoman shows her face' (90).

Tahitian Tehani, Byam's wife, is a stunning beauty, an orphan and the favourite niece of a childless chief depicted as the most powerful in Tahiti. She develops a deeply romantic and mutually loving relationship with Byam, bears him a loving daughter and dies soon after he is forced to return to England. In that respect, Tehani is a character who is much flatter than Byam. She stands in the line of Herman Melville's Fayaway in Typee (1846), or Pierre Loti's Rarahu in Le Mariage de Loti (1879): a lovelorn figure, she is left behind to die a romantic death 'in the moon of Pipiri, when [Byam is] three months gone' (378). However well documented Byam's narrative may be on Tahitian gender issues, Tehani is no more than a type. In Mutiny, the vahine fails to be much more than a foil to the European male protagonist. She is but a loving, faithful wife, dignified and respectable, and yet unsubstantial enough to be allowed to die, and disappear from the narrative altogether, as soon as her lover departs. As Rod Edmond argues, the vahine 'is the island'. ${ }^{35}$ Te hani in Tahitian means 'the land', 'the earth'; as a verb, hani can be used to describe 'a bond with the island', and the expression Ua hani te fenua ia 'oe may translate as 'the land has made you hers'. This strongly supports the idea that Tehani is the island. ${ }^{36}$ Like the island, she is eventually left and longed for by a self-indulgent and nostalgic European protagonist - a locus amoenus of colonial discourse.

34 Morrison's words are: 'the ladys who act these [licentious practices] are not to be taken as a standard for the Whole no more then the Nymphs of the Thames or Syrens of Spithead are to be taken as Samples of our own fair Country Weomen', in Smith \& Thomas (2013, p 264). Observations of the same kind were made by various other early commentators including Johann Reinhold Forster and Cook.

35 Edmond, 1997, p 75.

36 My warm thanks to Joudy Clark-Tefau, 2017-18 second-year undergraduate student at the University of French Polynesia, for her valuable information on the meaning of hani. 


\section{Life in Tahiti: Island ceremonies}

Roger Byam's wedding, the major Tahitian ceremony in Mutiny, might be a departure from the novel's dominant colonial discourse. Veihiatua Tehani's uncle and tutor, and the highest Tahitian chief - readily gives his assent to his favourite niece's wedding. Tehani, he claims, is 'a royal gift in truth. For three and seventy generations she can count her ancestors back to the gods!' (183). In comparison, Midshipman Byam confesses he is '[a] very small [chief in his own land], perhaps' (178). What looks like a glaring social mismatch devised to suit the erotic and racial fantasies of colonial discourse, may have been viewed by Tahitians as an excellent match. They may have thought that intermarriage with early contact foreigners come from 'beyond the sky' would increase their own spiritual force, or mana. ${ }^{37}$ This apparent foray into ancient island culture can suggest a postcolonial reading for Mutiny. Byam does indeed seem to fleetingly present the wedding from the Tahitian 'side of the beach': ${ }^{38}$

The priest ... called upon the mighty chiefs and warriors whose skulls stood before us, giving each man his full name and resounding titles, and calling upon him to witness and bless the union of Tehani with the white man from beyond the sea. (188, my italics)

But the narrator does not proceed to explain that, for Tahitians, the expression 'white man from beyond the sea' is much more than exotic poetry. Byam does not account for the wedding from a Tahitian perspective. He reduces it to the folkloric crowning of a romantic love bond, as Westerners would have it. Readers consequently must accept as appropriate that the European male protagonist should marry into the most powerful Tahitian family, and that the wedding should be an occasion for much pomp and circumstance. The Tahitian wedding ceremony is accordingly described in some length over four pages (185-88). It does provide interesting, relatively accurate ethnographic information, ${ }^{39}$ but the fact that the European bridegroom should be so complacently

37 Dening, 1992, pp 160-61; Tcherkézoff, 2004, p 19. This theory was originally presented by Marshall Sahlins about Hawaiian and Fijian societies in Islands of History (Chicago \& London, University of Chicago Press, 1985).

38 Dening, 2004, p 54.

39 For the description of a historical native wedding ceremony between a Tahitian woman and a European sailor (1792), see 'Extracts from a Log-Book of HMS Providence, kept by Lieut Francis Godolphin Bond RN, on Bligh's second Breadfruit Voyage, 1791-3' (Journal of the Royal Australian Historical Society, vol 46, no 1, pp 24-57, in Salmond, 2011, p 365). 
the focus of all attention once again brackets the narrative as colonial discourse. Any attempt at sketching Tahitian identity is defeated by an overruling assertion of colonial British identity.

The major island ceremony that took place during the historical Bounty beachcombers ${ }^{40}$ Tahitian sojourn was Pomare II's investiture. It celebrated the victory of the Pomares over their rivals. Morrison draws a clear picture of Tahitian political rivalries at the time. Three main groups had been struggling for hegemony:

1. The Seaward Teva. Vehiatua at their head, based in Taiarapu.

2. The Landward Teva. Purea at their head, based in Papara.

3. The Porenu'u. Tu, alias Teina, or the Pomare line at their head, based in Pare-Arue-Matavai. ${ }^{41}$

In Mutiny, island rivalries are only fleetingly mentioned: the reader is told that 'Vehiatua is the king of the smaller island - the most powerful of the Indian princes. His realm is richer and more populous than those of his rivals' (69), but this only serves to enhance the prestige of Byam's father-in-law. At one point, Charles Churchill makes a flippant allusion to serving as a mercenary to Vehiatua, to fight against the chief's rivals:

'I like the old chief - your father-in-law, whatever he is - and he seems to like me. He's a fighting man, and so is the other chief, Atuanui. We were planning a bit of a war last night. He says if I'll help him he'll give me a piece of land, with a young wife thrown in.' (196)

But it all sounds rather hypothetical, and Churchill is killed before any war breaks out. Local warfare is mostly presented as a backdrop, a kind of theatrical stage prop: '[o]f furniture there was scarcely any: ... a stand of weapons hanging on one of the pillars which supported the ridgepole, including my host's ponderous war club' (81).

40 'Beachcombing [is] the act of repudiating Western civilisation by jumping ship, crossing the beach and attempting to join an island culture' (Edmond, 1997, p 17).

41 A map of these rival groups may be found in Smith \& Thomas (2013, pp 88-134, 185-219). See also Dening (1992, pp 179-80); Salmond (2011, pp 268-77). 
Mutiny thus fails to show how fierce Tahitian wars were, and how dramatically the Bounty residents 'shaped events in Tahiti, in ways disproportionate to their numbers' ${ }^{42}$ As recorded in Morrison's journal, ${ }^{43}$ the beachcombers' firepower transformed local warfare, destroyed an ancestral balance of power and radically changed the face of island history.

The mutineers from the Bounty offered their services as mercenaries and furnished arms to the family which became the Pōmare Dynasty. The chief $\mathrm{Tu}$, alias Teina, or Pōmare, knew how to use their presence in the harbors favoured by sailors to his advantage. As a result of his alliance with the mutineers, he succeeded in considerably increasing his supremacy over the island of Tahiti. ${ }^{44}$

In Mutiny, however, this historical watershed is stymied into wishful thinking. Upon the Pandora's arrival, high chief Teina ingenuously conjectures:

that Cook and Bligh, if the latter chanced to be with him, would now decide to remain permanently at Tahiti; he [Teina] would urge them to do so, and would set aside great tracts of land for their use and provide them with as many servants as they might want; with their help he would bring the whole of Tahiti under subjection; then we would all proceed to the island of Eimeo, and on to Raiatea and Bora Bora, conquering each of these islands in turn. And he promised that Stewart and I [Byam] should be made great chiefs, and that our children should grow in power after us. (209)

William Bligh had tricked Tahitians into believing that James Cook was still alive but, by 1789 , they knew that he was dead. ${ }^{45}$ The imagined consequences of the arrival of Cook and Bligh on the Pandora are indeed described here as delusory (with the repeated use of 'would' and 'should'), but the aim is to imply that prospects of British-supported wars never materialised in Tahiti. The narrator's tone is condescending to Teina, as if the primitive high chief should be excused for indulging in such wild dreams. This presentation of things is blatantly at odds with the historical truth. Also, the narrative exonerates the beachcombers of any mercenary

42 Nicholas Thomas, Islanders: The Pacific in the Age of Empire, Boston, Yale University Press, 2010, pp 21-22.

43 Smith \& Thomas, 2013, pp 115, 116.

44 Alexander, 2003, p 12.

45 Tahitians were informed of Cook's death first in 1788 (three months before the Bounty's first call) by seamen from the Lady Penrhyn, and again in 1789 (one month before the Bounty's last call) by the captain of the Mercury. 
meddling by transferring the onus - albeit virtually - onto British officers Cook and Bligh. Since Cook and Bligh consistently refused to take part in local warfare, ${ }^{46}$ it may be surmised that the authors wish to keep most Bounty mutineers - and more specifically their hero - clear of any moral stain, as in typical popular fiction.

Teina's victory did occur, with the decisive help of the Bounty beachcombers. He gradually took control of most Society Islands, an unprecedented achievement, and the Pomare dynasty remained in power until the French abolished the native monarchy in $1880 .{ }^{47}$ The Bounty residents, as well as Bligh during his second Tahitian stay, were able to witness the six-month-long ceremony of young Pomare II's investiture, over 'weeks of extravagant feasting'. Morrison reports gruesome details about 'rows of human sacrifices, thirty of them':

[the priest] took an Eye out of each, with a Piece of split bamboo, and placing them on a leaf took a Young Plantain tree in one hand, and the Eyes in the Other Made a long speech holding them up to the Young King, who sat above him with his mouth open ... [T] he reason that the King sits with his Mouth open, is to let the Soul of the Sacrafice enter into his Soul, that he may be strengthened thereby, or that His Tutelar deity or Guardian Angel presides to receive the Soul of the Sacrafice ... [T] he Human sacrifices offered this day were 30 , some of which had been Killd near a Month. ${ }^{48}$

This pharaonic ceremony could hardly have escaped the beachcombers' notice, nor easily been forgotten. Yet Pomare II's investiture is conspicuously absent from Mutiny. The figure of the Noble Savage remains untainted. As far as Tahitian ceremonies are concerned, Byam's wedding stands alone to the fore - colonial discourse prevails.

46 On Cook, see James Cook \& James King, A Voyage to the Pacific Ocean. Undertaken, by the Command of his Majesty, for Making Discoveries in the Northern Hemisphere. Performed Under the Direction of Captains Cook, Clerke, and Gore, in his Majesty's Ships the Resolution and Discovery. In the Years 1776, 1777, 1778, 1779, and 1780. In Three Volumes, vol 1 (London, 1784, pp 190-201). On Bligh, see Salmond (2011, p 79).

47 See Jean-François Baré, Le Malentendu Pacifique. Des premières rencontres entre Polynésiens et Anglais et de ce qui séensuivit avec les Français jusqu’à nos jours (Paris, Hachette, 1985); Bruno Saura, Histoire et Mémoire des Temps Coloniaux en Polynésie Française (Pirae, Au Vent des Îles, 2015).

48 Smith \& Thomas, 2013, p 132. 


\section{Life in Tahiti: Going native}

The second main difference between the Tahitian narratives of Peter Heywood and Roger Byam lies in their choice of a residence in Tahiti. Like most of the Bounty beachcombers, Heywood only 'crossed' part of 'the beach': he chose to live in Matavai, the port of call of all British ships. He first moved in with Scottish Midshipman George Stewart, and then settled down with his Tahitian wife nearby, on the land of Stewart's wife. Nearly all of the Bounty residents remained in groups of two to five. Except for occasional short trips to other villages, they were never isolated from one another for long. ${ }^{49}$

Like many of the Bounty beachcombers, Heywood once took a trip to Taiarapu, Vehiatua's stronghold at the other end of the island. Like James Morrison, William Muspratt, Thomas Burkitt, Charles Churchill and others, he was offered the chance to settle down there. These invitations were proffered in the context of local warfare, with a mind to coaxing more beachcombers to Taiarapu - but Heywood declined the offer. ${ }^{50} \mathrm{He}$ remained in Matavai where he adopted a Tahitian lifestyle: he agreed to be further heavily tattooed, he learnt the Tahitian language and he gained considerable insight into the Tahitian way of life. Like all the Bounty beachcombers, he was wholly dependent on his taio and the Tahitian ari 'is ${ }^{51}$ goodwill: it was 'their relationship to the highly ranked Tahitians that kept at bay much ordinary envy and anger at their presence'; they were given land, shelter and protection, in return for duties like acting as mercenaries. $^{52}$

Two notorious troublemakers, Bounty Master-at-Arms Churchill and Able Seaman Matthew Thompson, became 'the epitome of the licentious and roguish beachcomber'. ${ }^{3}$ Part of their historical tale must be told to underscore the differences with Byam's narrative. Thompson raped a young girl, then;

49 Most of the Bounty beachcombers lived in Matavai or neighbouring Arue and Pare.

50 Smyth, 1831b, pp 102-05, 304-05.

51 Taio: Tahitian word for friend. For an extensive study of the word's meaning, see Vanessa Smith, Intimate Strangers: Friendship, Exchange and Pacific Encounters (Cambridge, Cambridge University Press, 2010). Ari $i$ : Tahitian word for a nobleman, or high chief.

52 Dening, 1992, pp 213-58.

53 Dening, 1992, p 217. 
[he] shot a man dead, together with the infant he was carrying. The man was a visitor from another island, totally innocent and ignorant of what had happened in relation to the girl. In the disorder that followed, Churchill ... volunteered to be the general of [the beachcombers'] army and the men's captain. It was an offer that the others refused, and, by gifts and diplomacy, they quieted the situation. As a result, Churchill went off with Thompson to Taiarapu, at the other end of the island. There his ambition to be a leader of some sort, a passion for command that had bedevilled them since the day of the mutiny, was fulfilled. His taio, Vehiatua, the ari i of the Seaward Teva, died and, in some way, Churchill was made arii in his place.

... Aware that Thompson was bitterly jealous of his honours and fearful of the dangers in that, Churchill had Thompson's weapons stolen. Thompson then returned to Matavai, persuaded the others to lend him a musket and returned to Taiarapu, where he killed Churchill. Enraged that he had killed their chief, one of the Teva ... battered him to death. ${ }^{54}$

In Mutiny, unlike Heywood, Byam chooses to 'cross the beach' further, by living away from Matavai and all the other Bounty beachcombers. He agrees to settle down in his wife's village - precisely in 'Taiarapu, at the other end of the island'. When Vehiatua welcomes fugitive Churchill and Thompson, Byam declares that this is done on his own account: 'Vehiatua, supposing him to be one of my friends, had welcomed [them]' (195, my italics). Older Byam's narrative does not account for the fate of Churchill and Thompson from a Tahitian perspective. As a result, first, Vehiatua is stripped of his political acumen, and reduced to the blindly obliging Tahitian stereotype, a feature of the Noble Savage. Second, the narrative focus shifts onto Byam's younger self, giving the European protagonist all the credit for a decision of the most powerful Tahitian ari i is. In a blazingly colonial kind of discourse, Byam is made to wield supreme authority over Vehiatua, both as older narrator and as younger protagonist.

Byam explains that Churchill and Thompson had to look for a place far away from Papara whose leaders were 'allied with the clan to which the murdered man belonged' (195). But he fails to say that the two fugitives' choice of Taiarapu was not due to distance only. More importantly, they sought refuge in the bulwark of the "hostile alliance'55 against Papara, under the protection of Vehiatua who was glad to be friendly with his

54 Dening, 1992, pp 217-18. For further information on these events, see Douglas Oliver, Ancient Tahitian Society (Honolulu, University of Hawai'i Press, 1974, chpt 28).

55 Salmond, 2009, p 84. 
foes' foes. The narrative also significantly fails to signal that Churchill was raised to the ranks of Vehiatua's taio and of ari i $i$. In the novel, the old chief's good health endures, so Churchill does not inherit his title. Ironically enough, at the extradiegetic level, rivalries are displaced here, from historical Tahitian chiefs to non-historical European characters: in Mutiny's Taiarapu, Byam shall be the one and only 'white man from beyond'. Nobody shall vie for his position of honour.

Byam's choice of a residence miles away from all the other Bounty mutineers illuminates the figure of a white man solitary among natives i.e. gone native. Here is a dialogue between Byam and Stewart, who once pays his friend a visit:

[Stewart:] 'What a place for a hermit's meditations!'

'Would you like to live here?' I asked.

'Perhaps. But I would miss the sight of English faces. You, Byam, living alone among the Indians, do you never miss your own kind?'

I thought for a moment before I replied: 'Not thus far.'

Stewart smiled: 'You are half Indian already.' (201)

There is dramatic irony in Stewart's comment that Byam is 'half Indian'. Byam does not quite go native: throughout the Tahitian narrative he says that he is not there to stay. He constantly reminds the reader of his twin duties to Britain: his mother, and Joseph Banks' Tahitian dictionary. He has a 'civilised' excuse for going native: even in the places farthest removed from European civilisation, he has 'not a care in the world, save the making of [his] dictionary' (85). Although there was no tradition of writing in Tahiti, Byam's gentle vahine 'leav[es him] free to do [his] writing' (189-90). Coincidentally, Byam never debases himself to the duties of a mercenary: ${ }^{56}$

The loss of Churchill was accepted as an unfavourable omen by Vehiatua's priests, and the expedition planned against the people of the south coast of Eimeo was given up. I was secretly glad to be freed from the duty of taking up arms against men to whom I bore no ill-will, and settled down with relief to a tranquil domestic life and my studies of the Indian tongue. (197)

56 Heywood did fight in several skirmishes, see Peter Heywood's letter to this mother, 20 Nov 1791, Batavia, ML M 3075, in Salmond (2011, p 400). 
Mutiny is no postcolonial Pacific Heart of Darkness - Tautira is a far cry from the upper Congo River, and Byam and Kurtz go native in dramatically different ways. Byam's life is the Western fantasy of island life at its most idyllic. Crusoe-like, Byam is immersed in exotic nature but with enough Western culture to preserve his British identity.

The finale of colonial discourse in the narrative of life in Tahiti coincides with the Pandora's arrival. As soon as the Tautirans sight the Pandora, they launch their canoes and reach Matavai much before her; yet, 'news of the ship precede[s]' the Tautiran sailors to the port of call. There might be an allegorical reading to this race: however well-performing the Tahitian society, or whatever their nautical, cultural, political, and other achievements, they are subdued by 'news' or narratives. It is a colonial narrative that shapes the readers' representations of Tahiti. As Byam sails back to Matavai on board Tuahu's canoe, he gives what sounds like a farewell song, a litany of Tahitian place names: 'Pueu ... Hitiaa ... Tiarei'. When he finally reaches Matavai, he stops at Tahara'a - renamed 'One Tree Hill' by Samuel Wallis (204). 'One Tree Hill' are the closing words of the chapters on Tahiti. Nomen est omen: the British place name, and colonial discourse, triumph in the narrative of Tahitian life.

\section{Roger Byam's court martial and closing framing narrative}

Older narrator Byam is allowed to warp Tahitian history so as to make the European male protagonist, his younger self, the undivided centre of narrative focus. The question asked at the court martial of younger Byam, ${ }^{57}$ whether his tale of the mutiny is reliable, may therefore sound ironical. This intriguing mise en abyme of narrative reliability in Mutiny, however, raises fresh questions about literary discourses and genres. But first, what are the main differences between Peter Heywood's and Byam's experiences of a court martial?

57 This study deliberately leaves out the eventful voyage back home, the narrative of which is largely historically accurate in Mutiny. 
Younger Byam returns to England an orphan, because his mother and only remaining family has been dealt a fatal blow by William Bligh's scathing letter about his 'baseness ... beyond all description' (224). Those were indeed historical Bligh's words to Mrs Heywood, but they did not kill her: she was spared reading them by a wide, caring circle of family and friends.

Peer Heywood and Byam both made/make emotional pleas. They appeal/ed to the court's feelings of pity with regards to their extreme youth and innocence. Here are extracts from Heywood's plea:

My parents (but I have only one left, a solitary and Mournful Mother who is at home weeping and trembling for the event of this day) [should be considered, to determine] the consolation or settled misery of a dear mother and two Sisters who mingle their tears together and are all but frantic for my situation. ${ }^{58}$

One of the sisters, Nessy, did do 'frantic' lobbying. She appealed to a powerfully affluent and influential network of close relatives and friends. ${ }^{59}$

Byam's plea reaches even higher emotional peaks, by expanding on the image of a wronged orphan and noble boy victim. His sole support (not lobbyist) and eventual saviour is Banks - which is ironic because historical Banks patronised Bligh all along.

In history, Heywood and James Morrison were found guilty of the charge of mutiny, sentenced to death and pardoned by King George III. William Muspratt was released on a legal technicality. In Mutiny, Morrison, Muspratt and Byam are all found guilty. Morrison and Muspratt are pardoned. Byam, on the other hand, is proved innocent after a tense 22-page-long suspense involving fictional events: Robert Tinkler, given for lost, reappears at the 11th hour and bears testimony just before the hanging. As a result, the court 'are convinced of [Byam's] entire innocence of the crime of mutiny' (352). The protagonist is once again singled out for his moral values, the only Bounty beachcomber to be proved 'as innocent as Sir Joseph' (363). Thus put on an equal footing with Banks, Byam's national identity is clearly outlined. This leaves little doubt as to the Mutiny's literary discourse and genre: a colonial narrative that preserves British morality. An epitome of popular literature, it delivers gripping

58 Owen Rutter (ed), The Court Martial of the 'Bounty' Mutineers (Edinburgh \& London, William Hodge, 1931, pp 147-48).

59 See Maxton \& Du Rietz (2013). 
melodrama. As to younger Byam's reliability, the court acknowledges 'the truth of every statement' he has made. To the readers' emotional relief, his narrative of the mutiny is deemed reliable.

The tale delivered at court martial, however, is but a short one embedded within several other tales. It is a tale within Byam's tale of the Bounty events, embedded within Byam's journal. The journal itself is embedded within the framing narrative of older Byam's tale, delivered 55 years after the events. This mise en abyme raises issues of validity, owing to distance and added reports. Any attempt to determine this historical novel's degree of contingency must thus question the reliability of narrator Byam - not the younger narrator, but the older one.

The Mutiny's Epilogue briefly states that Byam fights the Napoleonic wars, and his valiant role at Trafalgar earns him the rank of captain. This peremptorily confirms the hero's British identity and ultimate recognition by his British peers. Deeply nostalgic, however, middle-aged Byam manages to call back at Tahiti in 1810 , on a passage to New South Wales where 'Bligh was once more the central figure of a mutiny' (371). ${ }^{60}$ In Tahiti, Byam finds nothing but desolation: in the last 20 years, most of his friends and family have succumbed to the so-called 'fatal impact' of their contact with Westerners. ${ }^{61}$ His daughter, a rare survivor, has grown into a replica of his twin lost loves: 'she had all her dead mother's beauty, and something of my mother as well' (379). Feeling that he no longer belongs there, Byam chooses not to make himself known to her, and leaves Tahiti forever. Byam and Tahitians, including his own daughter and grandchild, have become irretrievable strangers to one another.

The Epilogue evinces significant changes from the source material. Unlike Byam, Heywood enjoyed speedy promotion to the highest rank of post-captain, thanks to his influential friends. He never sailed back to Tahiti. He left the Navy to become Admiralty hydrographer, got married and died in 1831, aged 58. ${ }^{62}$ In comparison, Byam's military record is

60 The Rum Rebellion: Bligh was then governor of New South Wales, and the object of a rebellion from the military officers. Mutiny fleetingly shows Bligh in one of his outbursts, still the same uncontrollably violent speaker in 1810. For further information on the Rum Rebellion, see Salmond (2011, Epilogue).

61 South Pacific postcolonial literature decries the 'fatal impact' argument: see, for example, fictions like Keri Hulme's The Bone People (1984), Patricia Grace's Potiki (1987), Alan Duffs Once were Warriors (1990) and Albert Wendt's The Mango's Kiss (2003).

62 For more detailed information on Heywood's subsequent career compared to that of other Bounty members, see Smyth (1831a, pp 468-81). 
more glorious and, by remaining single, the hero retains the status of romantic lover required by this genre of popular literature. The Epilogue also delivers colonial discourse where otherness is clearly delineated: there can be no more cultural or ethnic bridging in the Tahiti of 1810 , no more talk of crossing the beach and going native. Native culture itself is moribund. Banks' reaction against freshly acquitted Byam's plan to return to Tahiti proves literally right: 'the islands ... no, my lad!' One only goes there to 'bury [one]self' (363). The novel's closing words, 'the place was full of ghosts, - shadows of men alive and dead, - my own among them' (379), illuminate what Rod Edmond defines as the twin colonial mantras of nostalgia for a place of perfect happiness forever lost, and of a Pacific island people doomed to become extinct after the West's fatal impact. ${ }^{63}$

\section{Roger Byam's opening framing narrative}

What about the opening frame's all-encompassing narrator? The year is 1843; 73-year-old Byam is about to deliver his embedded Bounty narrative in the form of an analepsis. So the beginning is actually the end, and the Epilogue is a false end. From the start, readers are thus alerted to ambivalences. Ambivalence characterises the narrator-protagonist also: he is both an older narrating 'I', and a younger narrated 'I'. May there be more to Byam than meets the eyes, after (or before) all? Whereas the younger voice recounts the events, the older voice reflects on those to-be/ have-been events. It also hints at the untold tale of Byam's life since 1810 - a life of emptiness and profound nostalgia, which remains unsaid. What matters may lie in this other, untold tale.

The opening narrative (3-5) may prove decisive to this chapter's argument: an underlying feeling of oppression and a craving for liberty run through its lines. In conservative, never-changing Britain, the old man complains: 'Forty years of this life have made a slave of me' (my italics). Older Byam's freedom may only be gained through writing about the past - 'to be free to wander in the past' (my italics) - and, more specifically, about Tahiti. The opening frame thus operates a gradual shift, through writing, from oppression to freedom, from the present to the past, and

63 Countering the 'fatal impact' argument, Edmond writes: 'Pacific historians and anthropologists have emphasised the resilience and continuity of Pacific societies in the colonial period. Far from being wiped out, they adapted and survived, often conceding less than contemporary missionary accounts, for example, were prepared to admit' (Edmond, 1997, p 14). 
from Britain to Tahiti. In that respect, the opening narrative foreshadows the main narrative, since writing is presented as a means of liberation throughout the novel: in Tahiti, 'the making of [his] dictionary [gives Byam] sufficient occupation to prevent ennui' (85); on the Pandora, the same writing activity lifts 'the prohibition' against speaking Tahitian (242); in jail, the 'manuscript pages' allow Byam's mind to wander off to 'Tahiti' (342); and it is finally his own written plea of innocence that results in his avoiding hanging. The opening framing narrative, with its focus on the liberating virtues of writing, might therefore be seen as a miniature mirror image of the main narrative.

Older Byam's tale of oppression, however, sounds almost comic: his gaoler is 80-year-'old Thacker', the family's 'housekeeper' who 'will listen to no hint of retirement'. Byam's self-mocking tone, his 'inward amusement' may indicate dramatic irony: the older narrating 'I's ironical distance from his own narrated 'I' may give readers a hint to follow suit and be critical of Byam's overall representations of things. Older Byam clearly invites readers to relativism, as he puts to the test a number of 18 th-century hierarchies. His very first words challenge national hierarchies: 'The British are frequently criticized' - which gives him an excuse to decry Britain and the British Navy as a narrow-minded, self-enclosed set. Life in Britain's West Country, he argues, 'conform[s] to the patterns of a simpler age' (my italics), which looks, one might think, intriguingly similar to life in primitive places. Likewise, Byam begs to be 'pardoned a not unnatural tenderness towards the scene of his youth' (my italics): first, the stress on his own natural side makes him once more singularly akin to 'natural' Tahitians (7); and, second, the fact that Byam speaks of himself in the third person clearly marks distancing. With the male master 'a slave' to the female servant, Byam further questions gender and social hierarchies. He carries on challenging racial hierarchies when he notes that 'Seven generations of Byams have lived and died in Withycombe [but] at my death what remains of our blood will flow in the veins of an Indian woman in the South Sea' (5). This next confession again strongly urges relativism: 'Insignificant in the annals of the Navy, and even more so from an historian's point of view, [the Bounty] incident was nevertheless the strangest, the most picturesque, and the most tragic of my career'.

Older Byam's voice of relativism may urge readers to put his embedded narratives into perspective. 'It makes me smile to-day to think of [my past candidness]' (15), he later engagingly says. He acknowledges that his perceptions as a younger man may have been deceiving: 
[At court martial] We were objects of curiosity to everyone, and many of the officers stared at us as though we were wild animals. At least, so it seemed to me, but no doubt I was unusually sensitive at that time, and imagined insolence and hostility on faces which revealed nothing more than natural curiosity. (321)

While awaiting hanging, Byam ponders the effects of changing lights and changing mental perspectives:

Even the common objects in my small cabin, - the locker, the table, and the inkwell before me, - seen in various lights at different hours of the day, I found beautiful and wondered that I had failed to notice such things before. (340)

At times, he is a self-confessed deficient narrator: 'I never felt that I truly understood the workings of [Bligh's] mind and heart' (141); or a selfconfessed censor: 'Of my interview with his mother I shall not speak' (367). In terms of literary genres, this double voice allows the character of popular fiction to evolve into the rounder character of a Bildungsroman. It also calls for metaliterary relativism: in a kind of self-commentary, or relativism mise en abyme, Mutiny invites readers to ponder over the issue of narrators' reliability:

It was my opinion at the time of the court-martial, and it is so still, that [Hayward] arranged his recollections of what had taken place [during the mutiny] so as to put his own actions in the most favourable possible light. (315)

That is relativism with a vengeance, exposing older Byam's opinion on younger Byam's opinion on Thomas Hayward's opinion on the Bounty mutiny. Equally interesting is this conversation in New South Wales in 1810, when Byam discusses William Bligh and the Rum Rebellion:

[Pascoe:] 'What have you heard of all this in England?'

[Byam:] 'Only rumours; we know nothing of the truth.'

[Pascoe:] 'The truth is hard to get at, even here. No doubt there is justice on both sides.' (372)

The Rum Rebellion being another 'mutiny' (371), such balance in pronouncing judgement on Bligh is arresting.

It seems that, all along, older Byam knows that, since his narrative is autobiographical, it will be biased. That is exactly what the opening frame seems to alert readers to. Framing narratives can, and often do, play a vital 
role in the narratives they frame: ${ }^{64}$ it might apply here. Why should there be a relativist opening frame in Mutiny, if not to deliver a tongue-in-cheek variation of the main narrative's leitmotiv on oppression, and thereby tone it down? '[O]ld Thacker', the so-called tyrannical housekeeper, is clearly a parody of tyrannical Bligh. This parodic introduction might hint that the embedded description of Bligh's tyranny is also exaggerated - that narrated Bligh is also a parody of historical Bligh. While reading over older Byam's shoulder, readers may ponder old Thacker's and Bligh's tyrannical ways. Likewise, the self-derisively overstated metaphor, 'a slave', applied to older Byam, may announce another possibly equally overstated metaphor, 'hell' (153), which historical Fletcher Christian claimed he suffered under Bligh's command.

Another of older Byam's whimsical confessions is a paragon of selfderision and ambivalence: 'I continue, almost against my will, to live by the clock' (4). While talking about his life in Withycombe, is he not also hinting at his failure to leave the Bounty at the time of the mutiny? Indeed, he comically presents himself as the passive victim of outside animation out of his control - in Withycombe: 'seven finds me dressing', 'my copy of the Times would reach me at ten'; similarly, on the Bounty, the mutiny finds him 'too late' to board a launch that 'had drifted astern' seemingly of its own accord (139). It is as if older Byam were nudging readers into caution when he protests that he cannot be blamed for his own actions, neither now nor then. It is as if he were urging them to deride him. All he seems to have retained from his life experiences is a commitment to punctuality - funnily enough, 'too late' - of derisory value in retired life. Self-mocking Byam gives Mutiny additional literary interest: hovering over the flat protagonist of popular fiction, there is a more nuanced and challenging older narrator, a rounder character who is likely to attract a more analytical kind of readership. The multiplicity of narrative voices might orient the narrative away from the popular historical novel towards a higher, more reflexive and more thought-provoking literary genre.

The all-encompassing older narrator might also be said to challenge colonial discourse in Mutiny as a whole. Owing to the framing narrative, Byam appears as a fragmented self, which is a result of having 'crossed the beach'. His self might be too fragmented to give a unified and coherent representation of the British. His voices might be too many to sound an

64 See H Porter Abott, The Cambridge Introduction to Narrative (2nd edn, Cambridge, Cambridge University Press, 2009, pp 28-39). 
unequivocal hymn to the Navy. Cultural relativism hints that otherness might be found at home, too. When Byam finds himself free again in London, he mourns, 'I was alone, among strangers, for the first time in five years' (356). Likewise, in the following quote, the word 'savage' and the use of the demonstrative 'those' marks the narrator's distance from his own culture:

Sea Law. Just - yes; just, savage, and implacable. I would have given the whole of the Articles of War and all those who wrote them to have had Tom Ellison [one of the hanged mutineers] sitting, in the flesh, opposite me in that seat in the London coach. (355)

Older Byam's criticism of Britain, his longing for the South Sea and his overall relativism contribute to questioning the narrative of a British unitary identity.

Mutiny's colonial discourse, however, remains unchallenged. However fragmented, the European self is the undisputed narrative focus. Although he has 'crossed the beach', older Byam's moralising voice never questions the wisdom of Joseph Banks' insistence on a linguistic mission being sent to Tahiti, which facilitated Western settling in the Pacific. Not once does he reflect on his own active role in the fatal impact he decries: with the other Bounty beachcombers, he unwittingly participates in Pacific island depopulation through the spread of European diseases, guns and British lifestyle. His profound nostalgia for Tahiti remains self-centred and only serves a colonial mantra. However relativist, Mutiny remains a Eurocentric and egotistic narrative. Writing imprisons the older narrator in the narrative of his own past. The narrating ' $\mathrm{I}$ ', writing his memoirs about the narrated 'I' writing his journal, produces nothing but a cyclical, self-enclosed and self-centred narrative. Writing thus mise en abyme binds the writing narrator in endless repetition. The 'camphorwood box' wherefrom older Byam retrieves his journal in 1843 is but another 'Pandora's box': it tightens the chains around him. In this way, older Byam is bound to repeat the same plea for forgiveness: 'an old man ... may be pardoned a not unnatural tenderness' (3). His plea for 'pardon' and excuse of extreme 'old' age echoes younger Byam's plea and excuse of 'extreme youth' at court martial. Older Byam still craves the same need for self-exculpation and identification to blameless British peers: 
It has long been my purpose to follow the example of other retired officers and employ the too abundant leisure of an old man in setting down, with the aid of my journal and in the fullest detail, a narrative of some of the episodes of my life at sea. (5)

What eventually matters in Mutiny's whole narrative is colonial discourse founded on British identity, however subjected to criticism that identity may be.

Nordhoff and Hall, like older Byam, were constantly and sometimes excruciatingly balanced between home in the United States and Tahiti. ${ }^{65}$ Like older Byam, they turned to writing in an attempt to define their own selves. But while writing 'from the beach' in Tahiti, they chose to adopt a British narrator's viewpoint. Their narrative choices in Mutiny buttress Byam's colonial discourse. Like him, they longed for things Western, since they elicited to represent Tahiti from a British perspective, with a strong focus on the British protagonist. They failed to practise their older narrator's preaching in cultural relativism. This might ultimately explain their choice of an imaginary white male narrator-protagonist: they created Byam in their own image - a Byam with their own bias. ${ }^{66}$

Their narrative of the Bounty was mostly a commercial venture, urged by Ellery Sedwig, the editor of the Atlantic Monthly, who convinced them that the story would sell well. Writing about Tahiti was, to a certain extent, a variant of colonial exploitation. Somewhat like Banks' self-styled civilising missions to transfer breadfruit to slave-owners and to write a Tahitian dictionary for British mariners, their narrative of Mutiny further contributed to the stereotypically colonial representation of Tahiti as a carefree island where natives lived in 'a timeless, myth-ridden, ahistorical haze'. ${ }^{67}$ Their South Sea narrative is conventionally romantic and their purpose in writing was to sell, not to make a breakthrough in the history of Pacific literature. Nor did they aim to write highbrow or innovative literature. Whatever their forays into narrative strategies, what they wrote was colonial discourse in the genre of a popular novel parading as historical.

65 For a detailed biography of Nordhoff and Hall, see Paul L Briand, Jr, In Search of Paradise: The Nordhoff-Hall Story (Honolulu, Mutual Publishing Paperback Series, 1966).

66 Nancy Hall does not know where Roger Byam's name comes from: 'As far as she thought, it was made up.' Personal communication from Cindy Overhardt, James Norman Hall's granddaughter, reporting her mother's answer to my written enquiry, 21 Mar 2014. I find the Byam-bias paronomasia rather tantalising.

67 Salmond, 2009, p 33. 


\section{Conclusion}

At times, Mutiny fleetingly strikes a postcolonial stance. By vindicating the Tahitian vahine, it makes a genuine attempt at discarding a prevailing Tahitian stereotype and delineating some features of Polynesian identity. By fragmenting the narrator's identity, it likewise invites cultural relativism. Yet, colonial discourse prevails in the way the narrative deals only incidentally and superficially with local politics, culture and gender issues, and does not balk at reconstructing the Bounty mutiny and Tahitian history to the advantage of the British protagonist. In keeping with colonial discourse, Tahitians are stereotypes of Noble Savages, while Roger Byam stands out as the archetypal British romantic. He may go temporarily 'half native', but his main concern is constantly to reaffirm a clearly defined British national identity. Byam returns home and his lovelorn Tahitian lover and her island soon perish, according to the sweepingly colonial fatal impact argument. While writing Mutiny, Nordhoff and Hall were gazing at far-away Britain from Tahiti, and their narrative strategies converged to produce colonial discourse in a popular romantic novel. Whereas Mutiny on the Bounty was acclaimed as a historical novel, it turns out to be mostly fictionalised history. As such, it has widely contributed to spreading enduring myths, not only about William Bligh but also, in collective Western representations, about Tahiti. Illustrating this resilience, John Boyne's more recent popular historical novel, Mutiny on the Bounty (2008), does strive to restore Bligh's name, but still shows little concern for Tahiti. For instance, in blatant dismissal of Tahitian culture, it describes the breadfruit - a key element to any Bounty narrative - as 'an extraordinary thing ... growing in the soil'. ${ }^{68}$ Such misinformation and neglectful documentation in the age of internet clearly pertains to colonial discourse. To echo Greg Dening and Gérard Genette, a popular, postcolonial Mutiny on the Bounty remains to be written 'from the indigenous side of the beach', 'where the British would be seen, described and judged by Polynesians' and where 'thematic and axiological viewpoints' would be duly inverted. ${ }^{69}$

68 Boyne, 2008, p 213.

69 The original quote is 'a Friday, where Crusoe would be seen, described and judged by Friday' (my translation), in Gérard Genette, Palimpsestes, La Littérature au Second Degré (Paris, Seuil, 1982, pp 419, 424). 
This text is taken from The Bounty from the Beach: Cross-Cultural and Cross-Disciplinary Essays, edited by Sylvie Largeaud-Ortega, published 2018 by ANU Press, The Australian National University, Canberra, Australia. 